\title{
Impact of ocean acidification on a key Arctic pelagic mollusc (Limacina helicina)
}

\author{
S. Comeau ${ }^{1,2}$, G. Gorsky ${ }^{1,2}$, R. Jeffree ${ }^{3}$, J.-L. Teyssié 3 , and J.-P. Gattuso ${ }^{1,2}$ \\ ${ }^{1}$ CNRS-INSU, Laboratoire d'Océanographie de Villefranche, BP 28, 06234 Villefranche-sur-Mer Cedex, France \\ ${ }^{2}$ Université Pierre et Marie Curie-Paris 6, Observatoire Océanologique de Villefranche, 06230 Villefranche-sur-Mer, France \\ ${ }^{3}$ Marine Environmental Laboratories, International Atomic Energy Agency, 4 quai Antoine $1^{\mathrm{er}} 98000$ Monaco, \\ Principality of Monaco
}

Received: 23 December 2008 - Published in Biogeosciences Discuss.: 26 February 2009

Revised: 13 August 2009 - Accepted: 16 August 2009 - Published: 4 September 2009

\begin{abstract}
Thecosome pteropods (shelled pelagic molluscs) can play an important role in the food web of various ecosystems and play a key role in the cycling of carbon and carbonate. Since they harbor an aragonitic shell, they could be very sensitive to ocean acidification driven by the increase of anthropogenic $\mathrm{CO}_{2}$ emissions. The impact of changes in the carbonate chemistry was investigated on Limacina helicina, a key species of Arctic ecosystems. Pteropods were kept in culture under controlled $\mathrm{pH}$ conditions corresponding to $p \mathrm{CO}_{2}$ levels of 350 and $760 \mu \mathrm{atm}$. Calcification was estimated using a fluorochrome and the radioisotope ${ }^{45} \mathrm{Ca}$. It exhibits a $28 \%$ decrease at the $\mathrm{pH}$ value expected for 2100 compared to the present $\mathrm{pH}$ value. This result supports the concern for the future of pteropods in a high- $\mathrm{CO}_{2}$ world, as well as of those species dependent upon them as a food resource. A decline of their populations would likely cause dramatic changes to the structure, function and services of polar ecosystems.
\end{abstract}

\section{Introduction}

The oceans have absorbed about one third of total anthropogenic $\mathrm{CO}_{2}$ emissions since 1800 (Sabine et al., 2004). Although this uptake of greenhouse gases limits global warming, it also causes profound changes in the chemistry of seawater such as a decrease of $\mathrm{pH}$ referred to as "ocean acidification". Global mean surface ocean $\mathrm{pH}$ has decreased by about 0.1 unit since the end of 18th century and, accord-

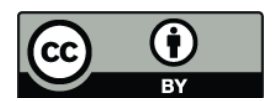

Correspondence to: S. Comeau (comeau@obs-vlfr.fr ) ing to model projections, will decrease by another 0.3 unit by the end of the present century (Caldeira and Wickett, 2003). Such $\mathrm{pH}$ decrease will coincide with a decrease in the carbonate ion concentration of 55\% (Brewer, 1997) which could severely impact most calcifying organisms such as corals and corraline algae (Gattuso et al., 1998; Langdon and Atkinson, 2005), commercial molluscs (Gazeau et al., 2007) or phytoplankton (Riebesell et al., 2000). Effects of ocean acidification are already detectable, for example, since the end of $18^{\text {th }}$ century a $30-35 \%$ decline of Antarctic foraminifera shell weights has been reported (Moy et al., 2009).

Pteropods are pelagic molluscs that are highly specialized for life in the open ocean. They are commonly referred to as "sea butterflies", due to the evolution of their gastropod foot into wing-like parapodia that allow them a pelagic existence (Lalli and Gilmer, 1989). They filter-feed and produce large mucus webs for collecting mostly phytoplankton but also small zooplankton or their juveniles (Gilmer and Harbison, 1986; Harbison and Gilmer, 1992; Gannefors et al., 2005). The "shelled pteropod" species produce a calcium carbonate shell; the only shelled pteropod in Arctic waters is Limacina helicina, a species that can occur in high densities in both Arctic and Southern Ocean. Limacina helicina is also an important component of marine food webs. For example in the Southern Ocean it is frequently very abundant (up to $2681 \mathrm{ind}^{-3}$ ) and is a major dietary component for zooplankton and higher predators such as herring, salmon, whale and birds (Hunt et al., 2008; Karnovsky et al., 2008). Shelled pteropods may also play a geochemical role in the oceans, as significant contributors to the export of carbonate (order $10 \%$ of the global $\mathrm{CaCO}_{3}$ flux, Berner and Honjo, 1981) and carbon to the deep ocean (Collier et al., 2000).

Published by Copernicus Publications on behalf of the European Geosciences Union. 
There is great concern about the potential impact of the consequences of ocean acidification on high-latitude organisms and ecosystems. Models predict that the surface waters of the polar oceans will be the first to become undersaturated with respect to aragonite in 2050 in the Southern Ocean (Orr et al., 2005; McNeil and Matear, 2007) and as early as 2016 in the Arctic Ocean (Steinacher et al., 2009). Pteropod shells are made of aragonite, a metastable form of calcium carbonate more soluble than calcite in seawater (Mucci, 1983). These key organisms, are therefore expected to be highly sensitive to ocean acidification.

The rate of calcification for four pteropod species (none of them Limacina helicina) were reported by Fabry (1990) but despite their important role in the food web as well as in the cycling of carbon and calcium carbonate, not a single study has investigated their response to ocean acidification. Here we report on the first measurements of calcification of a pteropod in perturbation experiments where the $\mathrm{CO}_{2}$ partial pressure $\left(p \mathrm{CO}_{2}\right)$ and temperature were controlled. The rate of calcification of Limacina helicina was measured under $1990\left(p \mathrm{CO}_{2}=350 \mu \mathrm{atm}\right)$ and end-of-century conditions $\left(p \mathrm{CO}_{2}=765 \mu \mathrm{atm}\right)$ consistent with Intergovernmental Panel on Climate Change (IPCC) projections.

\section{Materials and methods}

\subsection{Sampling}

Pteropods were collected in Kongsfjorden, Svalbard (Fig. 1) during the period 19 May to 8 June 2008. West Spitsbergen is influenced by a branch of the North Atlantic Current that carries warm and saline waters. Kongsfjorden is an open fjord, submitted to the influence of the Atlantic and Arctic waters (Svendsen et al., 2002).

Jars mounted on sticks were used to collect animals swimming near the surface, the bottom depth was less than $250 \mathrm{~m}$. This method avoided the stress and damage to the body or the shell which can occur with nets. Pteropods were immediately transported to the Kings Bay Marine Laboratory in Ny-Ålesund, and maintained in 51 beakers under controlled conditions. The seawater used in the experiments was pumped at $80 \mathrm{~m}$ and filtered on $20 \mu \mathrm{m}$ filters. The beakers were temperature-controlled at $5^{\circ} \mathrm{C}$ and gently stirred using slowly rotating plastic paddles $(10 \mathrm{rpm})$.

\subsection{Measurement of the carbonate chemistry}

Seawater $\mathrm{pH}$ was measured within one hour of collection on a field sample collected 30 May. It was also measured in the experimental beakers, using a $\mathrm{pH}$ meter (Metrohm, $826 \mathrm{pH}$ mobile) with a glass electrode (Metrohm, electrode plus) calibrated every second day on the total scale using Tris/HCl and 2-aminopyridine/ $\mathrm{HCl}$ buffer solutions with a salinity of 35.0 (Dickson et al., 2007). Total alkalinity (TA) was measured on a field sample collected on 30 May as

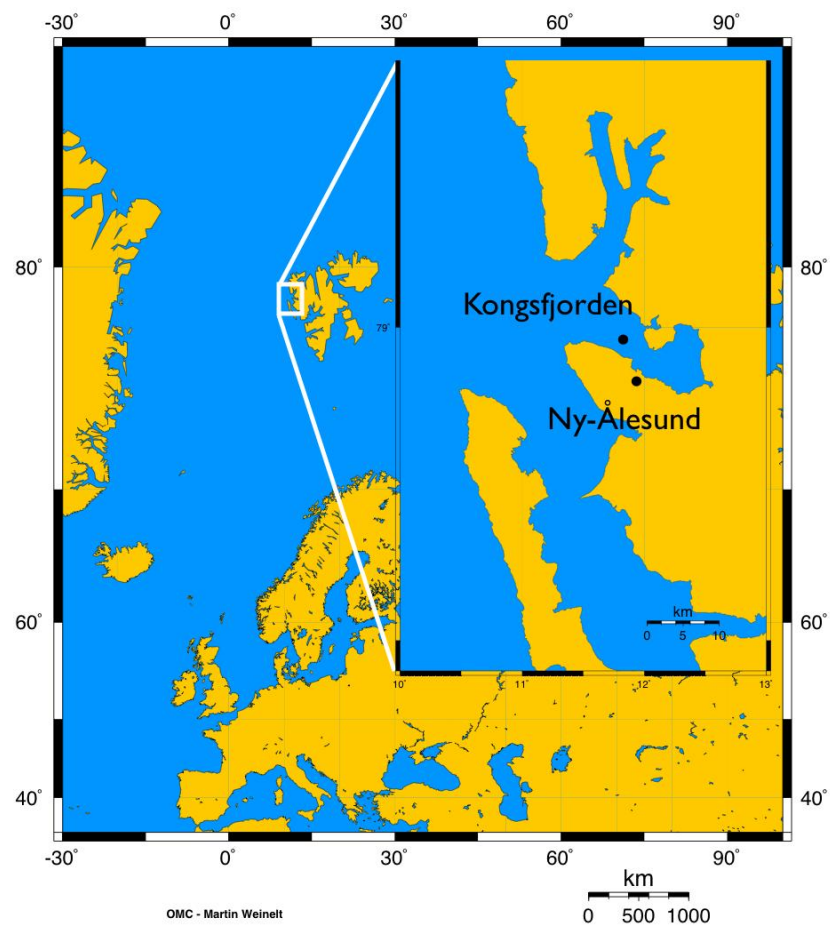

Fig. 1. Location of the field experiment. Pteropods were collected in the Kongsfjorden. Experiments were carried out at the marine laboratory in $\mathrm{Ny}$-Ålesund $\left(78^{\circ} 55^{\prime} \mathrm{N} 11^{\circ} 56^{\prime} \mathrm{E}\right)$.

well as in experimental samples which were filtered, poisoned with $\mathrm{HgCl}_{2}$ and stored in a cool dark place pending measurement. It was determined potentiometrically using a home-made titrator built with a Metrohm $\mathrm{pH}$ electrode and a 665 Dosimat titrator. Measurements were carried out on $20 \mathrm{ml}$ samples at $25^{\circ} \mathrm{C}$ and TA was calculated using a Gran function applied to the $\mathrm{pH}$ values ranging from 3.5 to 3.0 as described by Dickson et al. (2007). Titrations of a total alkalinity standard provided by A. G. Dickson (batch 80 ) were within $0.7 \mu \mathrm{mol} \mathrm{kg}-1$ of the nominal value (standard deviation $=2.6 \mu \mathrm{mol} \mathrm{kg}^{-1} ; n=8$ ). The concentration of dissolved inorganic carbon (DIC) and the saturation state of aragonite $\left(\Omega_{a}\right)$ were determined from $\mathrm{pH}_{T}$ and total alkalinity using the R package seacarb (Proye and Gattuso, 2003).

\subsection{Calcein staining}

A batch of 50 pteropods, freshly collected and transferred to the laboratory, were stained in a calcein bath for $1 \mathrm{~h}$ (final concentration: $50 \mathrm{mg}^{-1}$ ). The animals were then rinsed by successive transfers in unstained seawater. They were maintained for $5 \mathrm{~d}$ in 51 beakers under controlled conditions of $\mathrm{pH}$ and temperature. $\mathrm{pH}$ was controlled at either 7.8 or 8.09 using a continuous $\mathrm{pH}$-stat system (IKS, Karlsbad) that bubbled either $\mathrm{CO}_{2}$-free air or pure $\mathrm{CO}_{2}$ depending on the desired $\mathrm{pH}$ value. Sea water for TA measurements was collected daily. Upon completion of the incubation, only active 
(or swimming) pteropods were sampled and observations made under UV-epifluorescence using a Leica DM2000 microscope.

\section{$2.4{ }^{45}$ Ca uptake}

Freshly collected pteropods were incubated with ${ }^{45} \mathrm{CaCl}_{2}$ $\left(16 \mathrm{~Bq} \mathrm{ml}^{-1}\right)$ in four 51 beakers at two $\mathrm{pH}$ levels. Two groups comprised 18 animals each and served for time point 0 (actually about $1 \mathrm{~min}$ exposure to ${ }^{45} \mathrm{Ca}$ ) while the other groups comprised 54 animals each and served for time points 2, 4 and $6 \mathrm{~h} . \mathrm{pH}_{T}$ was maintained at 7.78 (low $\mathrm{pH}$ ) and 8.09 (normal $\mathrm{pH}$ ) by continuous, gentle bubbling of air or $\mathrm{CO}_{2}-$ enriched air generated by a gas mixing pump (Wösthoff, Bochum).

Six animals were sampled in triplicate at times $0,2,4$ and $6 \mathrm{~h}$, rinsed with unlabelled seawater, gently dried with a tissue to remove seawater, and weighed $( \pm 0.1 \mathrm{mg})$. Shells were dissolved with $0.5 \mathrm{~N} \mathrm{HNO}_{3}$ and soft tissues were tissuedried and weighed. The solutions were then neutralized using $2 \mathrm{~N} \mathrm{NaOH}$ and $10 \mathrm{ml}$ of scintillation liquid (Ultima Gold, PerkinElmer) added. Counting was performed with a Packard scintillation counter. An identical protocol was used with pteropods killed by $\mathrm{HgCl}_{2}$ prior to incubation in order to estimate the non-biological incorporation of ${ }^{45} \mathrm{Ca}$ in the shell. The amount of $\mathrm{CaCO}_{3}$ incorporated in the shell was:

$$
Q_{\mathrm{CaCO}_{3}}=\frac{1}{A_{S} \cdot M_{\mathrm{Ca}} \cdot P}\left(\frac{R_{l}}{W_{l}}-\frac{R_{d}}{W_{d}}\right)
$$

where $Q_{\mathrm{CaCO}_{3}}$ is the calcium carbonate precipitated $\left(\mu \mathrm{mol}(\mathrm{g} \text { wet weight })^{-1}\right), A_{s}$ is the specific activity of ${ }^{45} \mathrm{Ca}$ $\left(\mathrm{Bq} \mathrm{mg}^{-1}\right), M_{\mathrm{Ca}}$ is the molar mass of ${ }^{45} \mathrm{Ca}\left(\mathrm{g} \mathrm{mol}^{-1}\right), P$ is the ratio of radioactive vs. non radioactive calcium (estimated using its relationship with salinity, Dickson et al., 2007), $R_{l}$ and $R_{d}(\mathrm{~Bq})$ are the radioactivity measured in the live and dead pteropods shells, $W_{l}$ and $W_{d}$ are the tissue wet weight (g) of the live and dead pteropods. Rates of calcification were derived by regressing $Q_{\mathrm{CaCO}_{3}}$ against time.

\section{Results}

Only one water sample was collected in the fjord; the values reported therefore do not provide information on the diurnal or geographic distribution of the parameters of the carbonate chemistry. Nevertheless, the parameters measured or estimated in the fjord are very close to those measured in the "normal $\mathrm{pH}$ " experimental condition (Table 1). The experimental values of $\Omega_{a}$ were 1.9 and 1.0 in the experimental conditions at $\mathrm{pH}_{T} 8.09$ and $\mathrm{pH}_{T} 7.78$, respectively.

The size range, based on the maximum diameter of the shell, was between 5 and $10 \mathrm{~mm}$ in the two experiments. The rate of survival after the 5-days period following the calcein staining was $100 \%$. The survivorship was obtained by counting pteropods under a binocular at the completion

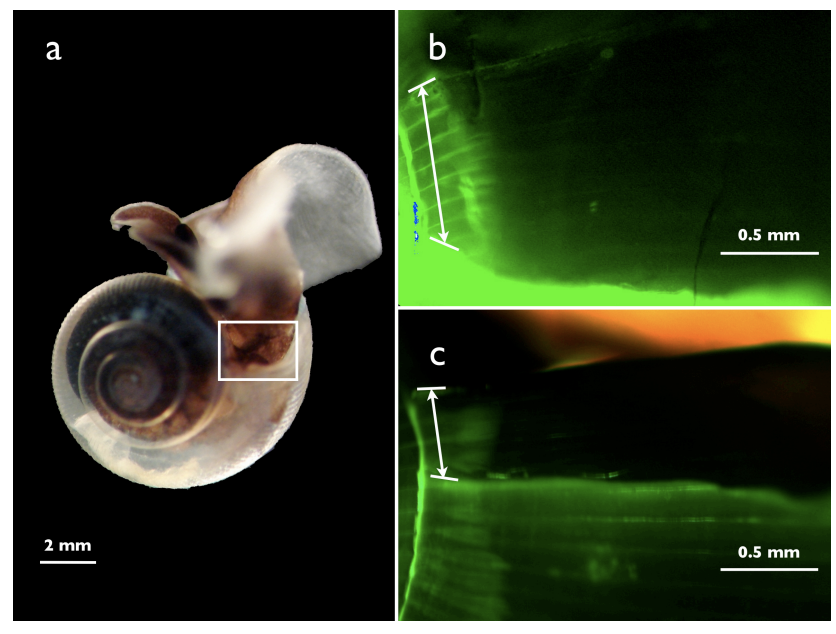

Fig. 2. Representative example of live Arctic Limacina helicina (a) stained with calcein and subsequently maintained at $\mathrm{pH}_{T} 8.09$ (b) and 7.8 (c). Most calcification occurs near the shell opening (white rectangle). The arrow indicates the 5 days linear extent of the shell.

of the 5 day experiment. Although all pteropods were alive, only $30 \%$ were active swimmers. The others stayed at the bottom of the beaker and exhibited little activity. The fluorochrome calcein was successfully incorporated in the shells of living pteropods (Fig. 2). The dark part of the shell corresponds to the calcification that occurred over the 5 days following staining and demonstrates that the organisms were viable and performed calcification in both culture conditions. Qualitative examination of stained pteropods suggests that the linear extension of the shell during the 5-days period following staining was lower in individuals maintained at the low $\mathrm{pH}$ condition than in those maintained at higher $\mathrm{pH}$. Too few organisms were photographed to provide statistically robust quantitative estimates of shell extension. The linear extensions measured are provided as a supplementary information (see http://www.biogeosciences.net/6/1877/2009/ bg-6-1877-2009-supplement.zip).

The non-biological adsorption of ${ }^{45} \mathrm{Ca}$ on the shell was $0.25 \pm 0.029$ (mean $\pm \mathrm{SD}, n=10, \quad p<0.001) \mu$ mol $\mathrm{CaCO}_{3}$ (g wet weight) ${ }^{-1} \mathrm{~h}^{-1}$. The calcification rate mesured during the $6 \mathrm{~h}$ incubation at $\mathrm{pH}_{T} 8.09$ (corresponding to a $p \mathrm{CO}_{2}$ of $\left.350 \mu \mathrm{atm}\right)$ was $0.36 \pm 0.027 \quad(n=10$, $p<0.001) \mu \mathrm{mol} \mathrm{CaCO}_{3}$ (g wet weight) ${ }^{-1} \mathrm{~h}^{-1}$ (Fig. 3). At $\mathrm{pH}_{T} 7.78$ (corresponding to a $p \mathrm{CO}_{2}$ of $765 \mu \mathrm{atm}$ ), the calcification rate was $0.26 \pm 0.018(n=10, p<0.001) \mu \mathrm{mol} \mathrm{CaCO}_{3}$ (g wet weight) $)^{-1} \mathrm{~h}^{-1}$. The coefficients of determination $\left(R^{2}\right)$ of the rates of calcification regressed against time were 0.96 at $\mathrm{pH}_{T} 8.09$ and 0.95 at $\mathrm{pH}_{T}$ 7.78. A comparison $t$-test confirmed that the slopes were statistically different $(t=3.0$, $p=0.02,9 \mathrm{df}$ ). The rate of calcification was $28 \%$ lower in the high than in the control $\mathrm{CO}_{2}$ level. The difference in calcification between the two $\mathrm{pH}$ conditions was not significant during the first $2 \mathrm{~h}$, significant during the first $4 \mathrm{~h}(p=0.05)$, and not significant during the last $2 \mathrm{~h}$ (hours 4 to 6 ) but no 
Table 1. Parameters of the carbonate chemistry in the two experimental conditions and in the natural condition (middle of the fjord). The concentration of dissolved inorganic carbon (DIC), partial pressure of $\mathrm{CO}_{2}\left(p \mathrm{CO}_{2}\right)$ and the saturation state of aragonite $\left(\Omega_{a}\right)$ were derived from $\mathrm{pH}_{T}$, total alkalinity, salinity and temperature.

\begin{tabular}{lccccccc}
\hline Conditions & $\mathrm{pH}_{T}$ & $\begin{array}{c}\text { Total alkalinity } \\
\left(\mu \mathrm{mol} \mathrm{kg}^{-1}\right)\end{array}$ & $\begin{array}{c}\mathrm{DIC} \\
\left(\mu \mathrm{mol} \mathrm{kg}^{-1}\right)\end{array}$ & $\begin{array}{c}p \mathrm{CO}_{2} \\
(\mu \mathrm{atm})\end{array}$ & $\Omega_{a}$ & Salinity & $\begin{array}{c}\text { Temperature } \\
\left({ }^{\circ} \mathrm{C}\right)\end{array}$ \\
\hline $\begin{array}{l}\text { Normal } \mathrm{pH} \\
(\text { year 1990) }\end{array}$ & 8.09 & 2298 & 2131 & 350 & 1.90 & 34.8 & 5 \\
$\begin{array}{l}\text { Low pH } \\
(\text { year 2100) }\end{array}$ & 7.78 & 2295 & 2237 & 765 & 1.00 & 34.8 & 5 \\
$\begin{array}{l}\text { Fjord (field } \\
\text { measurement })\end{array}$ & 8.12 & 2312 & 2148 & 320 & 1.81 & 34.9 & 2.2 \\
\hline
\end{tabular}

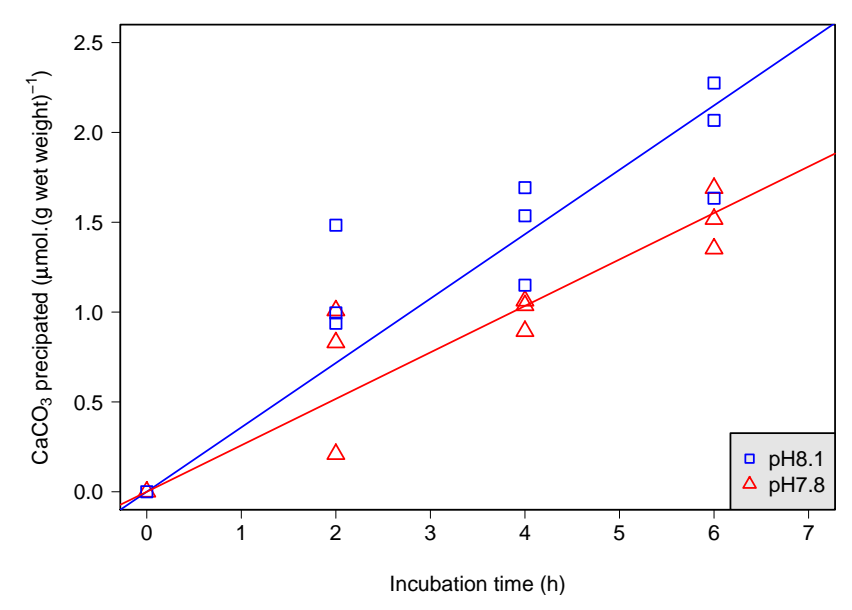

Fig. 3. Calcium carbonate precipitated as a function of time based on ${ }^{45}$ Ca uptake.

significant change was found, at each $\mathrm{pH}$, between the first $4 \mathrm{~h}$ and the last $2 \mathrm{~h}$ of the experiment.

\section{Discussion}

The Arctic Ocean is particularly vulnerable to the impact of seawater chemistry changes associated with ocean acidification. Models show that calcium carbonate undersaturation with respect to aragonite is expected as early as 2016 (Steinacher et al., 2009). Once the $p \mathrm{CO}_{2}$ values reaches $409 \mu \mathrm{atm}$, for at least one month of the year, the entire water column will become undersaturated with respect to aragonite $\left(\Omega_{a} \leq 1\right)$ in as much as $10 \%$ of the Arctic Ocean. These low saturation zones will be associated with increased melting of ice and freshwater inputs (Steinacher et al., 2009). Surface waters at our sampling location in Spitsbergen do not seem to be as vulnerable to aragonite undersaturation, as the aragonite undersaturation threshold $\left(\Omega_{a}=1\right)$ was reached by bubbling the fjord water with air having a $p \mathrm{CO}_{2}$ of $765 \mu \mathrm{atm}$.
At least two reasons could explain this difference. First, the sampling region is influenced by Atlantic water with high total alkalinity. Also, the experimental seawater pumped at 80 m was most likely a "Transformed Atlantic Water" (Cottier et al., 2005), less vulnerable to aragonite undersaturation than Arctic waters. Second, the experiments were carried out at a temperature of $5^{\circ} \mathrm{C}$ but lower temperatures occur in high Arctic waters further decreasing the solubility of aragonite.

This study is the first to provide both qualitative and quantitative evidence that increased ocean acidification affects calcification rates in pteropods. Calcein was previously used in studies of calcification in mussels (Reusch, 1998) and foraminifera (Erez, 2003). We show that calcein staining can also be used to investigate calcification in pteropods. It allowed comparison of the linear extension of the shells, which was lower at a $\mathrm{pH}_{T}$ of 7.8 than at a $\mathrm{pH}_{T}$ of 8.1 . It must be pointed out, however, that statistical inference is not possible due to the small size of the data set and that this result remains to be confirmed in future studies. It is recommended to standardize measurements of linear extension as its value significantly depends on the location of its measurement. Either the minimum extension (as shown in Fig. 2) or the maximum extension in the middle of the shell edge are the less subjective ways to proceed. Note also that linear extension is not always a good indicator of the rate of calcification, because it does not necessarily correlate with shell thickness and/or density.

The qualitative result obtained with calcein staining was confirmed by quantitative measurements of calcification in a ${ }^{45} \mathrm{Ca}$ uptake experiment. Previous studies have shown a rapid decrease of calcification in pteropods maintained for several hours in laboratory conditions (Fabry, 1990). In the present study, this effect was partly avoided by determining calcification rates on freshly collected animals, by minimising the sampling stress, and by limiting the incubation time to $6 \mathrm{~h}$. The decrease in calcification at the lower $\mathrm{pH}$ mostly occurred during the first $4 \mathrm{~h}$ of the experiment as calcification was similar in both $\mathrm{pH}$ conditions between 4 and $6 \mathrm{~h}$. However, the differences in calcification between the periods 0 to 
$4 \mathrm{~h}$ and 4 to $6 \mathrm{~h}$, within each $\mathrm{pH}$ conditions, are not statistically significant. We therefore discuss the rates of calcification obtained during the entire experiment. Future studies are needed to identify possible short-term, acute responses as well as possible acclimation. This will require the use of a larger number of individuals in order to increase statistical power and as well as to improve the maintenance of live pteropods to conduct perturbation experiments. The $28 \%$ decline of calcification in the lower $\mathrm{pH}$ condition is within the range reported for other calcifying organisms such as corals (Langdon and Atkinson, 2005). Previous work on benthic molluscs also showed a decrease in calcification with decreasing pH (Gazeau et al., 2007). L. helicina does appear to be well-adapted to low aragonite saturation conditions, however, as the ${ }^{45} \mathrm{Ca}$ experiments demonstrate that it can maintain a positive net calcification at the aragonite saturation threshold $\left(\Omega_{a}=1.0\right)$. In contrast, some organisms such as corals are unable to calcify at $\Omega_{a}=1.0$ (Langdon and Atkinson, 2005).

In the coming years, one may begin to witness a shift towards a negative balance between calcification and dissolution. Indeed, even if organisms can maintain calcification in undersaturated conditions, ocean acidification will increase the rate of dissolution of shells and skeletons. Pteropods are able to survive for 2 days in waters undersaturated with respect to aragonite but their shells show dissolution marks, casting additional doubt on their ability to achieve a positive balance between precipitation and dissolution of calcium carbonate (Orr et al., 2005). Furthermore, pteropods are vertical migrators that can cover several hundreds of meters per day (Wormuth, 1981). With the shoaling of the aragonite saturation state (Orr et al., 2005), pteropods might be exposed to increasingly corrosive waters during their daily migrations.

This work opens the way to new experiments on the effect of climate change on pteropods and highlights the critical need of new techniques enabling the maintenance of pteropods in the long term (several months). This would allow to avoid any stress related to sampling and to investigate the physiology plasticity and acclimation processes of pteropods. In the present study, temperature could not be maintained at its in situ level and experiments were carried out at a temperature $2.8^{\circ} \mathrm{C}$ higher than in situ. The lower rate of calcification found at the lower $\mathrm{pH}$ could therefore be the result of a response to both elevated $p \mathrm{CO}_{2}$ and temperature. Future experiments will need to take into account the combined effects of elevated $p \mathrm{CO}_{2}$ and temperature as it has been shown that the rate of calcification of the scleractinian coral Stylophora pistillata decreases by $50 \%$ under conditions of elevated temperature $\left(28^{\circ} \mathrm{C}\right)$ and high $p \mathrm{CO}_{2}$ (760 $\mu \mathrm{atm})$ whereas no effect was found when only $p \mathrm{CO}_{2}$ is elevated $\mathrm{CO}_{2}\left(p \mathrm{CO}_{2}=760 \mu \mathrm{atm} ; t=25^{\circ} \mathrm{C}\right.$; Reynaud et al., 2003).

The results of this study support the concern for the future of pteropods in a high- $\mathrm{CO}_{2}$ world, as well as of those species dependent upon them as a food resource. A decline of their populations would likely cause dramatic changes to the structure, function and services of polar ecosystems.

Acknowledgements. We thank M. Bartz, J. Buedenbender, S. Lischka, F. R. Oberhaensli, I. Werner and C. Thiriot for field and laboratory assistance, as well as J. A. Kleypas for very helpful comments on an early draft of the manuscript. Thanks are also due to three anonymous referees as well as to D. Roberts and E. V. Thuesen for useful comments on an earlier version of this paper. Logistic support from AWIPEV and Kings Bay is gratefully acknowledged. Contribution of the European Project on Ocean Acidification (EPOCA) with funding from the European Community (grant agreement 211384) and the French Polar Institute (IPEV).

Edited by: U. Riebesell

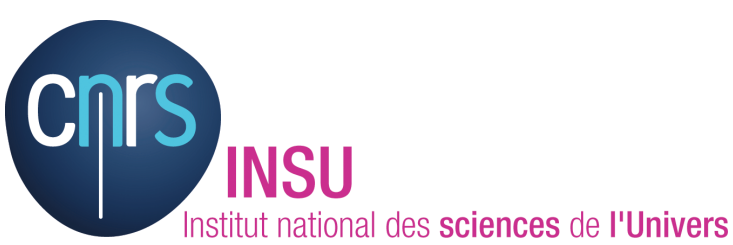

The publication of this article is financed by CNRS-INSU.

\section{References}

Berner, R. A. and Honjo, S.: Pelagic sedimentation of aragonite: its geochemical significance, Science, 3, 940-942, 1981.

Brewer, G. P.: Ocean chemistry of the fossil fuel $\mathrm{CO}_{2}$ signal: The haline signal of "business as usual”, Geophys. Res. Lett., 24, 1367-1369, 1997.

Caldeira, K. and Wickett, M. E.: Oceanography: anthropogenic carbon and ocean pH, Nature, 425, p. 365, 2003.

Collier, R., Dymond, J., Honjo, S., Manganini, S., Francois, R., and Dunbar, R.: The vertical flux of biogenic and lithogenic material in the Ross Sea: moored sediment trap observations 1996-1998, Deep-Sea Res. II, 47, 3491-3520, 2000.

Cottier, F., Tverberg, V., Inall, M., Svendsen, H., Nilsen, F., and Griffiths, C.: Water mass modification in an Arctic fjord through cross-shelf exchange: The seasonal hydrography of Kongsfjorden, Svalbard, J. Geophys. Res., 110, C12005, doi:10.1029/2004JC002757, 2005.

Dickson, A. G., Sabine, C. L., and Christian, J. R. (Eds.): Guide to best practices for $\mathrm{CO}_{2}$ measurements, PICES Special Publication, 3, 191 pp., 2007.

Erez, J.: The source of ions for biomineralization in foraminifera and their implications for paleoceanographic proxies, Rev. Mineral. Geochem., 54, 115-149, 2003.

Fabry, V. J.: Shell growth rates of pteropod and heteropod molluscs and aragonite production in the open ocean: implications for the marine carbonate system, J. Mar. Res., 48, 209-222, 1990.

Gannefors, C., Böer, M., Kattner, G., Graeve, M., Eiane, K., Gulliksen, B., Hop, H., and Falk-Petersen, S.: The Arctic sea butterfly Limacina helicina: lipids and life strategy, Mar. Biol., 147, 169177, 2005. 
Gattuso, J.-P., Frankignoulle, M., Bourge, I., Romaine, S., and Buddemeier, R. W.: Effect of calcium carbonate saturation of seawater on coral calcification, Global Planet. Change, 18, 37-46, 1998.

Gazeau, F., Quiblier, C., Jansen, J. M., Gattuso, J.-P., Middelburg, J. J., and Heip, C. H. R.: Impact of elevated $\mathrm{CO}_{2}$ on shellfish calcification, Geophys. Res. Lett., 34, L07603, doi:10.1029/2006GL028554, 2007.

Gilmer, R. W. and Harbison, G. R.: Morphology and field behavior of pteropod molluscs: feeding methods in the families Cavoliniidae, Limacinidae and Peraclididae (Gastropoda: Thecosomata), Mar. Biol., 91, 47-57, 1986.

Harbison, G. R. and Gilmer, R. W.: Diet of Limacina helicina (Gastropoda: Thecosomata) in Arctic waters in midsummer, Mar. Ecol. Prog. Ser., 77, 125-134, 1992.

Hunt, B. P. V., Pakhomov, E. A., Hosie, G. W., Siegel, V., Ward, P., and Bernard, K.: Pteropods in Southern Ocean ecosystems, Prog. Oceanogr., 78, 193-221, 2008.

Karnovsky, N. J., Hobson, K. A., Iverson, S., and Hunt Jr., G. L.: Seasonal changes in diets of seabirds in the North Water Polynya: a multiple-indicator approach, Mar. Ecol. Prog. Ser., 357, 291299, 2008

Lalli, C. M. and Gilmer, R. W.: Pelagic snails, the biology of holoplanktonic gastropod mollusks, Stanford University Press, 1989.

Langdon, C. and Atkinson, M. J.: Effect of elevated $p \mathrm{CO}_{2}$ on photosynthesis and calcification of corals and interactions with seasonal change in temperature/irradiance and nutrient enrichment, J. Geophys. Res., 110, C09S07, doi:10.1029/2004JC002576, 2005.

Mc Neil, B. I. and Matear, R. J.: Climate change feedbacks on future oceanic acidification, Tellus B, 59, 191-198, 2007.

Moy, D., Howard, W. R., Bray, S. G., and Trull, T. W.: Reduced calcification in modern Southern Ocean planktonic foraminifera, Nature Geosci., 2, 276-280, 2009.

Mucci, A.: The solubility of calcite and aragonite in seawater at various salinities, temperatures, and one atmosphere total pressure, Am. J. Sci., 283, 780-799, 1983.
Orr, J. C., Fabry, V. J., Aumont, O., Bopp, L., Doney, S. C., and Feely, R. A.: Anthropogenic ocean acidification over the twentyfirst century and its impact on calcifying organisms, Nature, 437, 681-686, 2005.

Proye, A. and Gattuso, J.-P.: Seacarb 1.2.3, an R package to calculate parameters of the seawater carbonate system, online available at: http://cran.at.r-project.org/web/packages/seacarb/index. html, 2003.

Riebesell, U., Zondervan, I., Rost, B., Tortell, P. D., Zeebe, R. E., and Morel, F. M. M.: Reduced calcification of marine plankton in response to increased atmospheric $\mathrm{CO}_{2}$, Nature, 407, 364-367, 2000.

Reush, T. B.: Differing effects of eelgrass Zostera marina on recruitment and growth of associated blue mussels Mytilus edulis, Mar. Ecol. Prog. Ser., 167, 149-153, 1998.

Reynaud, S., Leclercq, N., Romaine-Lioud, S., Ferrier-Pagès, C., Jaubert,J., and Gattuso, J.-P.: Interacting effects of $\mathrm{CO}_{2}$ partial pressure and temperature on photosynthesis and calcification in a scleractinian coral, Glob. Change Biol., 9, 1660-1668, 2003.

Sabine, C. L., Feely, R. A., Gruber, N., Key, R. M., Lee, K., and Bullister, J. L.: The oceanic sink for anthropogenic $\mathrm{CO}_{2}$, Science, 305, 367-371, 2004.

Steinacher, M., Joos, F., Frölicher, T. L., Plattner, G.-K., and Doney, S. C.: Imminent ocean acidification in the Arctic projected with the NCAR global coupled carbon cycle-climate model, Biogeosciences, 6, 515-533, 2009, http://www.biogeosciences.net/6/515/2009/.

Svendsen, H., Beszczynska-Møller, A., Ove Hagen, J., Lefauconnier, B., Tverberg, V., and Gerland, S.: The physical environment of Kongsfjorden-Krossfjorden, an Arctic fjord system in Svalbard, Polar Res., 21, 133-166, 2002.

Wormuth, J. H.: Vertical distributions and diel migrations of Euthecosomata in the northwest Sargasso Sea, Deep-Sea Res., 28, 1493-1515, 1981. 